\title{
The Implied Reader: Patterns of Communication in Kipling's Fiction for Children Manal Anwar Fathy Ahmed*
}

The purpose of this paper is to examine the patterns of communication used by Kipling in his Just So Stories: For Little Children and how children react with them. It analyses the strategies and techniques used by Kipling to urge children to interact with the stories. The study shows that Kipling is not only a storyteller but an illustrator and a poet who addresses children and changes them into critical readers. The study also proves that Kipling was so interested in the response of his little readers that he tried to urge them to interact with his funny stories.

Reader-response criticism began to gain more interest in the middle of the twentieth century. The pragmatic theories which shifted the focus of interest from the work of art to the audience attracted many critics at that time. In The Mirror and the Lamp M. H. Abrams shows that Sir Philip Sidney considers poetry as a means whose end is to extract different responses from its readers. He considers the needs of the audience as the basis of critical distinction and classifies the genres of poetry according to moral and social effects of each. Also Samuel Johnson believes that the artist exerts his creative ability for the pleasure of his readers as "the end of writing is to instruct; the end of poetry is to instruct by pleasing" (Abrams 19).

In the fifth edition of A Handbook of Critical Approaches to Literature (2005) Wilfred L. Guerin, Lee Morgan et al argue that the basic premises of reader- oriented theory shift emphasis from the text to the reader in the process of literary interpretation. Therefore, the techniques and strategies used to urge the reader to respond to the literary text become more important than the text itself. This is due to the supposed role of the readers as interpreters of the literary work. (Guerin 351)

Among the principal theorists of reader- response criticism, Hans Jauss, Norman Holland, Stanely Fish, and Wolfgang Iser are distinguished theorists. For Jauss, the literary work is not "universal" as it does not have the same effect on all readers of all times. It does not offer "the same view to each reader in each period" (Newton 222). He thinks that the literary work creates his own existence away from the material words of the text. The psychological and emotional influences of the reader take part in interpreting the work of art. Also, Norman Holland believes that the reader's personality affects his interpretation of the text. Moreover, Stanely Fish thinks that "the process of reading is dynamic" (Guerin 359). $\mathrm{He}$ means that readers interact with the text so that their interpretation

\section{"English Department, Faculty of Arts, Fayoum University, Egypt}


may change with every new reading. Therefore, readers must be aware of the literary techniques that are used to be able to interact with the text. Fish calls such readers "informed" readers. He argues that meaning is "what happens to readers" during reading (Guerin 341). The readers' interaction makes them "actually create a piece of literature as they read it" (Guerin 341). For Fish, interpretation is a process in which the readers depend on their linguistic ability to interact with the text. Thus a work of art can have more than one response as interpretation plays a great role in understanding the meaning.

According to Wolfgang Iser, the text is "nothing more than an experience of a cultured reader" (Newton 227). He argues that there is a great difference between scientific texts and literary texts. The texts that deal with concrete objects do not need the participation of the reader. They express independent, concrete truth which is not affected by the reader's individuality. However, the literary text needs a dynamic kind of reader who participates in forming the meaning of the text. He has to connect the text to his familiar world in order to help his imagination to visualize it.

Moreover, the literary text cannot offer the reader all the details and information he wants. Iser sees that too many details are boring and they hinder the reader's imagination. Therefore, there are a lot of "gaps" in the literary text. Iser believes that they are these gaps which "give the reader the chance to build his own bridges" in order to understand the meaning of the text and fill the gaps" (Newton 229). Thus, each individual reader will try to relate the fragments of the text to each other so as to fill the gaps. Therefore, the interpretation of the text will depend on the reader's imagination, experience, and how he comprehends it. This interprets why a second reading of a literary text usually results in different impressions from the first reading. The norms and values of the reader help him to analyse the behavior of the different characters he is reading about. Furthermore, the creative and active imagination of the reader helps him to comprehend the underlying meaning of the dialogues among characters and to be in a state of suspense.

Iser believes that the reader must think of the underlying meaning which is beyond the surface meaning. He must consider the implied indications of the text. The result of this interactive task of the reader is what Iser calls "the virtual dimension of the text" (Lodge 298). This virtual dimension is the result of mixing the text and the imagination of the reader.

Iser differentiates between the "implied reader" who is in the mind of the author while writing and the "actual reader" who really reads the text 
and interacts with it (Selden 53). He believes that during the process of reading, the reader goes from "anticipation" to "retrospection" in order to adjust and revise his expectations of the text (Lodge 300.) He classifies the information together to form meaning. The reader continuously modifies his expectations and activates his imagination to visualize the information given to him. Iser thinks that the reader makes a state of "identification" with what he reads so that he creates "a familiar ground on which [he is] able to experience the unfamiliar" (Lodge 307).

Rudyard Kipling (1865-1936) was a talented and prolific author. In his early thirties his work received many critical studies. During his forties he reached the summit of his literary success as he became the first English author to receive the Nobel Prize for literature. Just So Stories was written in 1902 in South Africa. Kipling's experience there affected him so much that he depicted in his stories the leopard, the elephant, the jungle, the forests and the Limpopo River. At that time Kipling was interested in the idea of writing some children's stories about animals. Just So Stories are "for little children" so some of them are written to be read aloud to the pre-school age group. The stories have appeal to both adults as readers and children as listeners. Moreover, reading aloud is important for children because it "reveals how stories are crafted" and "brings alive the adventures, feelings and dilemmas of the characters" (Mallett 4). Sometimes Kipling starts a story addressing his daughter "O my best beloved" as he experienced telling these stories. $\mathrm{He}$ explains the title of the stories' series saying that they are bedtime stories that had to be told "just so" (Lewis xix).

The study concentrates on the first seven stories of Just So Stories because all of them are interesting animal stories. They are considered by Angus Wilson as the "cream of the collection" (qut. in Page 55). Moreover, there is a flagrant ongoing theme as Kipling, all the time, connects a prominent physical feature of an animal with a humorous and fanciful fact. In so doing, Kipling stereotypes each species of animals. This is contrary to the founders of children's realistic animal fiction who "focused on the individuality of their animal characters [and] avoided stereotyping the members of a given species" (Oswald 148). However, Kipling's animal characters "echo human virtues and vices" (Magee 224).

Children's writers suppose that young children respond happily to the music of words. They are also attracted by the interesting and funny progression of a story and its dramatic conflict, the lilt of verse, and the humorous incidents of the plot (MacCann, Donarae\& Richard, Olga 79). Kipling manages to achieve these requirements in his stories. Moreover, he is so interested in the illustrations to the extent that he himself draws them. The relationship between his stories and their illustrations is 
intricate. Without the illustrations and the long captions he adds to them, the stories seem incomplete. The illustrations have a narrative function because the child can follow the plotline of the story while looking at these pictures.

In her introduction to Just So Stories, Lisa Lewis suggests that "the most important linking theme in the book is ---the use and deliberate misuse of language" (Lewis xxxvi). This is done for the purpose of humor. Almost all types of humorous fiction for children, that are discussed by Kerry Mallan, are found in the stories. These types are humorous characters, humorous situations and humorous discourse. Mallan argues that "young children usually enjoy nonsense language and odd- sounding or inventive words" (Mallan 15). So, Kipling's coinage of words, word game, his duplicated onomatopoeic adjectives and odd little details are introduced to hold the ear of children and amuse them.

Kipling handles an obvious, physical feature of an animal in a funny style based on a false principle. This happens with the throat of the whale, the hump of the camel, the skin of the rhinoceros, and the spots of the leopard. However, children are intelligent enough to realize that Kipling's humorous explanation of those parts of the animals' bodies is not to be taken seriously. Moreover, there is an exaggeration of a specific characteristic like the greed of the whale and the curiosity of the young elephant. Furthermore, a frequent use of parentheses is found to provide the text with detailed information. Kipling uses a unique technique throughout the stories. He supports each story with two drawings elaborated by detailed captions and finally a poem that repeats the same theme of the story or is connected to it. Most of Kipling's poems are nonsense verse with fantastic themes. Margaret Mallett thinks that the vocabulary of nonsense verse is "often unusual, novel and amusing" because "nonsense rhymes are full of strange, eccentric folk and wonderful creatures with strange names" (Mallett 180).

However, before carefully examining Kipling's stories and how they affect children, it will be worthwhile to consider Jill May's ideas concerning how children respond to their stories.

In the preface to her book Children's Literature and Critical Theory (1995) Jill P. May explains that children read for pleasure before reading for information. She believes that children's "reading for enjoyment bring their own experiences with them and relate them to the story" (May viii ). After their first reading of the story, children become able to discuss it with others so that "they can become the implied reader" (May ix). In addition to this, May thinks that they can also examine the author's style, comprehend the meaning of the story, deduce their own conclusions and 
change into "critical readers" (May ix). Thus children can be developed from real readers to critical readers who can analyse and evaluate the literary elements that are used by the writer of the story.

According to May, active children readers must decide how a story "relates to their interpretation of the world they live in" (May 17). This helps them to understand the implied meanings of the stories. Moreover, the illustrations help children to visualize the heroes and their relationships. This merit of the illustrations becomes clearer particularly when the heroes are animals. The animals of these stories act as if they were human characters so that they are often "involved in moralistic tales about human failings" (May 46). Donnarae MacCann and Olga Richard argue that "characterization in picture books is usually a case of one idiosyncrasy being exaggerated and used as the basis for a whole chain of actions" (MacCann and Richard 92). This adds a sense of humor to the stories and makes the characters easily remembered. In so doing, children do as Iser believes. They activate their imagination and try to link the story they are reading to their familiar experiences (Lodge 307). They also achieve Stanely Fish's view that "the process of reading is dynamic" (Guerin 359) because they depend on their imagination to interpret the text and visualize the characters and events.

The response of the child reader to Kipling's "How the Whale Got his Throat" can be traced. Kipling starts the story addressing his own daughter "O my Best Beloved" (3). He begins talking about the greed of the whale saying that "He ate the star fish and the garfish, and the crab and the dab, and the plaice and the dace, and the skate and his mate, and the mackerel and the pickerel, and the really truly twirly- whirly eel" (3). Here, besides the funny rhythm he makes by all these kinds of fish, Kipling also uses the epithet which is a descriptive phrase in "really truly twirly- whirly" to describe the eel. The sound of this sequence of syllables gives a rhythmical effect which amuses children and lets them imagine the extent to which the whale is greedy.

To avoid being eaten by the whale, the fish advises him to "taste" the man. The man of the story is a ship-wrecked mariner who is with nothing on except a pair of blue breeches and a pair of suspenders. Here, Kipling repeatedly uses parentheses in which he reminds the child of the mariner's suspenders. These parentheses are not only used for a humorous effect but they make a kind of regular rhythmic pattern throughout the story. They show the steps of the conflict between the mariner and the whale and how he will make use of the suspenders to overcome the whale. From time to time he humorously addresses the child "(you must not forget the suspenders), ( you must particularly remember the suspenders)" 
(4). The usage of the parentheses makes the story seem realistic. Also, the tone is very intimate so that the child positively interact with the stories.

The whale saw the man and opened his mouth "back and back and back till it nearly touched his tail" and swallowed the mariner "and the raft he was sitting on" (4). This humorous exaggeration depicts a visual image for the child. He swallowed the man and his raft into his "warm, dark, inside cupboards" (4). There is a deliberate misuse of language in the word "cupboards" in reference to the stomach of the whale. Here, the child feels the problem that the man is facing. Moreover, he hopes that the man will win his struggle with the whale. The mariner makes many attempts to come out of the whale's inside body. To show the great effort exerted by the man and the troubles he makes to the whale, Kipling uses a series of rhyming, monosyllabic verbs in a kind of parallel structure. Michael Morpurgo believes that kipling "loves to play with sounds and rhythms of words" (Morpurgo).

The man---

stumped and he jumped and he thumped and he bumped, and he pranced and he danced, and he banged, and he clanged, and he hit and he bit, and he leaped and he creeped and he prowled and he howled, and he hopped and he dropped, and he cried and he sighed, and he crawled and he bawled, and he stepped and he lepped (5).

The whale becomes so tired that he hiccoughs. The word "hiccough" is a humorous onomatopoeic word which has a funny effect. In order to get rid of the hiccoughs, the whale agrees to take the mariner to his native shore. Yet, before leaving, the mariner cut up the raft into a little square grating and tied it firm with his suspenders into the whale's throat. The use of parentheses appears again to show the benefits of the suspenders "(now you know why you were not to forget the suspenders" (8). Kipling's direct addressing of the child here is urging him to think of the benefit of very simple things like suspenders. The child feels happy as he sympathizes with the man in his struggle with the whale. He also admires the mariner's intelligence in making use of the suspenders to overcome the problem he was facing.

Kipling adds to the story two illustrations with long captions. The first one depicts the whale swallowing the mariner. He describes the picture in detail giving both the whale and the mariner definite names. In the second picture he is showing his skill as an illustrator explaining the details of the picture in a funny way "I have drawn the door of the equator" (10). He, thus, activates the imagination of the child. 
In "How the Camel Got His Hump" Kipling again depends on his coinage of new language and word play to attract children. His word play appears in describing the desert as "howling" and the camel as "a Howler himself" (13). Of course this gives children a sense of humor so that they think of the meaning of the words. In addition to this, he chooses suitable plants of the desert saying that the camel eats "sticks and thorns and tamarisks and milkweed and prickles" (13). This indirectly shows children a variety of desert plants and adds a sense of reality to the story. They try to imagine the shapes of these plants and think of their suitability to the desert.

Kipling starts with generalization saying that the camel says "humph" to "anybody" who speaks to him. Then he uses a variation with the verbs used with animals according to the different tasks they do. The horse asks the camel to come out and "trot" (13), while the dog asks him to "fetch and carry" (14), and finally the ox asks him to "plough" (14). The camel's reply is "Humph" to the three animals. Therefore, the animals go and complain to the "Man"(14). This rhythmic repetition shows the frequent attempts made by the three animals to urge the camel to work. It also convinces the child that the camel deserves punishment.

The man or the master of the animals does not punish the camel but instead, he orders the animals to work double- time to make up for the idleness of the camel. The animals become angry and negotiate with each other to find a solution to this problem. Kipling here is so sarcastic of the animal's talks that he humorously says that they "held a palaver, and an indaba, and a punchayet, and pow-wow on the edge of the desert" (14). All of these are synonyms of the word "conference' and the word "punchayet" means a village council in India. These synonyms indicate that Kipling "was always the master of laughing words" (Morpurgo). He ironically considers their talks something serious. He thus conveys to the child reader a feeling of facing a dangerous problem.

The animals complain to the "Djinn in charge of All deserts" who was "rolling in a cloud of Dust" (14). Kipling adds an explanatory parenthesis because he is addressing a young reader "(Djinns always travel that way because it is Magic)" (14). The Djinn promises them "I'll humph him" (15). Kipling uses the word "humph" as a funny pun as it equates the word "hump". Then he draws an illustration of the Djinn making magic and explains, in a long caption, the magical instruments of the Djinn such as a magic pumpkin and a magic fan. Of course this is very astonishing to children who resort to their imagination to interpret the story.

After ending his argument with the Djinn saying "humph", the camel "saw his back, that he was so proud of, puffing up and puffing up into a great lolloping humph" (18). He tells the camel "that's your very own 
humph that you've brought upon your very own self by not working" (18). He adds that the camel can live on his "humph" for three days without eating. The Djinn orders him "Humph yourself" and the camel "humphed himself, humph and all" (18) and he joined the three animals in work. Kipling's wordplay is clear with the word "humph" which he sometimes uses as a verb and at other times as a noun. Then he adds a humorous, explanatory parenthesis "(We call it 'hump' now, not to hurt his feelings)" (18). Though he is sarcastic, he is teaching the young child how to be tactful. He adds a second illustration showing the very moment of adding the hump to the camel and also the new world with its volcanoes and mountains. The child enjoys Kipling's wordplay and thinks of the differences among the various elements of nature like mountains, volcanoes and deserts.

Kipling ends his story with a poem that calls for the privilege of work and warns that the lazy person will get a hump like that of the camel. He thus stresses the fact that a hump is a kind of punishment. Here, children enjoy Kipling's "nonesense language and odd-sounding or inventive words" (Mallan 15).

Kiddies and grown- ups too- oo-oo,

If we haven't enough to do- oo-oo,

We get the hump-

Cameelious hump-

The hump that is black and blue!

The poem of this story is closely related to its theme so that he coins the adjective "cameelious" to show its connection with the camel. It gives the child a moral lesson in a funny way that cannot easily be forgotten. He thus achieves what Samuel Johnson believes to be the aim of poetry which "is to instruct by pleasing" (Abrams 19).

"How the Rhinoceros Got His Skin" depicts a Parsee living by the Red Sea. He eats nothing except cake. To make one, he puts "flour and water and currants and plums and sugar and things"(23). The repetition of "and" shows the different ingredients of this delicious cake. The cake he baked "smelt most sentimental"(23). There is malapropism in this phrase because the sense of smelling is not suitable with the word "sentimental". This also makes the child more aware of scents and the sense of smelling. Then, appeared a rhinoceros whose skin had no wrinkles at that time. Yet he "had no manners then, and he has no manners now, and he never will have any manners"(24). This demonstrates the impoliteness of the rhinoceros in the past, present and future. Being afraid of the rhinoceros, the Parsee left the cake and climbed to the top of a palm- tree. The 
rhinoceros ate the cake. The Parsee recited the following Sloka which is a verse from the Sanskrit epics:

Them that takes cakes

Which the Parsee- man bakes

Makes dreadful mistakes.

This funny rhyme shows that something horrible will happen to the rhinoceros. This rhyme is enjoyed and easily remembered by the child.

Five weeks later, it was so hot that the "Rhinoceros took off his skin and carried it over his shoulder as he came down to the beach to bathe"(25). This is a humorous image that personifies the animal as if he were a person going to swim. Again he says that the rhinoceros left "his skin on the beach"(25). This is a fanciful image that likens the skin of the animal to a coat that can be taken off. The Parsee exploits the chance and puts cake -crumbs in the skin of the rhinoceros. The role played by man in taming the animals or punishing them is praised by Medlock who thinks that Kipling "makes an excellent micro-study in the basics of human-animal relations" (Medlock).

When the rhinoceros put on his skin, it tickled him. He "rolled and rolled and rolled" on the sands (25), but the cake crumbs tickled him "worse and worse and worse"(30). Moreover, he "rubbed and rubbed and rubbed himself" against a tree (30). The repetition of the verbs shows the agony of the rhinoceros and the frequent attempts made by him to get rid of this torturing feeling. It also gives a vivid imagery connected with the sense of touching. In a humorous way Kipling says that "from that day to this every rhinoceros has great folds in his skin and a very bad temper"(30). He once again gives a funny comment on the description of a part of an animal's body.

As usual Kipling makes two illustrations for his story. In the first one he draws the Parsee while making the cake. In the caption he calls the rhinoceros "Strorks" and adds ridiculous comments. Giving names to the animal adds a sense of individuality. In the second one he draws the Parsee waiting for the rhinoceros who was bathing without his skin. The illustrations here are helpful for the children to visualize the characters and realize their relationship.

In "How the Leopard Got His Spots" Kipling starts his story by telling his "Best Beloved" that the leopard lives in a place called the High Veldt. There is a lot of vivid imagery in giving careful description of the colors of things. The rock is "sandy- coloured" and the grass is "sandyyellowish" (33). Many animals live in the Veldet like the giraffe, zebra, eland, koodoo, and the hartebeest. They are "sandy- yellowishbrownish" but the leopard is the "sandiest- yellowest-brownest" of them all (33). This wordplay that consists of an epithet of onomatopoeic, 
rhythmic adjectives gives the child a visual image of the color and shape of the leopard. Moreover, there is an Ethiopian who ironically forms a team with the leopard for hunting. The man hunts with his "bows and arrows" whereas the leopard hunts with his teeth and claws. Again, Kipling uses a parenthesis in describing the Ethiopian who is "(a grayishbrownish- yellowish man)" (34). This is a humorous description of a human being. It suits Jill may's conviction that children read for pleasure before reading for information. This unusual vocabulary amuses them and provides them with fun.

The Leopard and the Ethiopian ran through the " 'sclusively greyish - yellowish - reddish" High Veldt but they don't have any kind of animals for their food(35). Kipling deliberately depends on wordplay in giving these colors. In their search for food, they met the Baviaan who is a dog - headed Baboon that is to say a big monkey. Kipling draws the Baviaan in the first illustration of the story to make it clear for children. His coinage of adjectives continues as he describes the "umbrellaish" thing about the Baviaan head as his "conventional Mane"(36).

While the leopard asks the Baviaan about the place of the "game", the Ethiopian asks him about the place of the "aboriginal Fauna" (35) meaning all the animals of the area. Kipling adds an explanatory parenthesis "(That meant just the same thing, but the Ethiopian always used long words. He was a grown up)"(35). He thus shows the child that the language of adult people is more complicated. He is addressing children in a very intimate way and from time to time stops to explain vividly to them.

The leopard and the Ethiopian found a forest full of trees "'sclusively speckled and sprottled and spottled, dotted and splashed and slashed and hatched and cross-hatched" with shadows (38). This alliterative, rhythmic epithet is humorous and it is for the purpose of oral pronunciation and oral rhyme. Kerry Mallan thinks that this kind of humorous discourse is preferred by children (Mallan 15). Kipling clarifies this intention in a parenthesis "(Say that quickly aloud, and you will see how very shadowy the forest must have been)"(38). Ordering children to say the words aloud makes them identified with the text and familiar with its environment.

The leopard manages to hunt a zebra while the Ethiopian succeeds in hunting a giraffe. Here, Kipling intensifies his concentration on imagery by addressing the sense of smelling then that of feeling and finally the 


\section{Manal Anwar Fathy Ahmed}

sense of seeing. By using a kind of parallel structure, the Leopard heard something breathing which "smelt like zebra, and it felt like zebra, and when he knocked it down it kicked like zebra"(39). Also, the man caught a thing that "smells like Giraffe, and it kicks like giraffe" (39). Yet because it was dark, they could not see what they caught. Here, Kipling is giving the reader a wonderful image of hunting which depends on hearing the victim's breath, smelling it and feeling it but not yet seeing it. However, the Zebra and the Giraffe manage to escape from them so that they only see "stripy shadows" of the Zebra and "blotched shadows" of the Giraffe (40). The Ethiopian and the Leopard decide to take the Baviaan's advice to change their shapes. The Ethiopian decides to change his skin to "a nice working blackish - brownish colour"(41). This epithet gives details of his new colour in a clear visual image. Moreover, he tells the leopard to take the Baviaan's advice and "go into spots" (41).

Here, there is a pun in the word "spots". The Ethiopian clarifies to the Leopard that the Baviaan "didn't" mean spots in South Africa. He meant "spots on your skin" (42). This is because he cannot hunt animals while he looks "like a sun - flower against a tarred fence" (42). The simile shows the clarity of the colour of the leopard in the darkness. So, the Leopard agrees to let the Ethiopian draws black marks with his five fingers on the Leopard's skin. Kipling's humorous comment appears here, as in other stories, in telling his "Best Beloved" that if she looks at any Leopard now, she "will see that there are always five spots - off five fat black finger- tips" (43).

Finally Kipling ends his story by a rhythmic pattern that is achieved by parallel structure and a lot of similes. This gives vivid imagery of the shape of the Leopard. The Ethiopian addresses the Leopard saying:

You can lie out on the bare ground and look like a heap of pebbles. You can lie out on the naked rocks and look like a piece of pudding - stone. You can lie out on a leafy branch and look like sunshine sifting through the leaves; and you can lie right across the centre of a path and look like nothing in particular (43).

These similes show the benefit of the new colour of the Leopard and how it will help him to be hidden from other animals in order to be able to hunt them. It seems that Kipling enjoys rhythmic language and playing with words so as to amuse children. Children, in their turn, love these 
stories "because of their extraordinary ingenuity and inventiveness" (Morpurgo).

The story ends with the second illustration showing the Ethiopian and a blurred image of the Leopard. Kipling humorously confesses that his illustration "is really a puzzle - picture like 'find - the - cat' " (44). This is to stress the fact that the spots hide the leopard. Thus the illustrations play a vital role in supporting the story and clarifying its events to the children.

"The Elephant Child" has a humorous beginning. The humorous effect is realized when Kipling claims that elephants in the far-off-times had no trunk. Instead they had "blackish, bulgy nose" (47). Moreover, the elephant's nose is "as big as a boot" (47). The exaggeration of this simile is also for the purpose of humor. The young elephant was very curious. Kipling uses deliberate misspelling in saying that the Elephant's child is full of "'satiable curtiosity" instead of "insatiable curiosity" (47). He thus uses his word play or word games with children to amuse them.

The Elephant's child asked the Ostrich about her tail - feathers, the Giraffe about his spotty skin, the Hippopotamus about his red eyes and the Baboon about the taste of melons. The reply of the animals is expressed in a kind of rhythmic repetition. The ostrich "spanked him with her hard, hard claw", the Hippopotamus "spanked him with her broad, broad hoof", the Giraffe "spanked him with his hard, hard hoof" and the Baboon "spanked him with his hairy, hairy paw" $(47,48)$. The variation of the parts used by animals in spanking him highlights the prominent organ of each animal. The Ostrich and the Hippopotamus are his "aunts" while the Giraffe and the Baboon are his "uncles". He thus likens the young elephant to the young child who has to be polite with the grownups. There is exaggeration again in saying that the elephant asked questions "about everything that he saw, or heard, or felt, or smelt, or touched" (48). This concentration on the different senses of the elephant reveals how curious he is.

When the Elephant's child asks about the dinner of the Crocodile, the bird advises him to go the banks of the "great grey- green, greasy" Limpopo River to find out (48). The epithet used here with its alliteration gives a distinguished rhythm while describing the river. The music of the words is amusing to the children. The Elephant begins his journey to the Limpopo River. However, till that "week, and day, and hour, and minute", the Elephant had never seen a crocodile (49). The gradual 


\section{Manal Anwar Fathy Ahmed}

decreasing of the time unit shows his insistence on knowledge and his ignorance of the danger of a crocodile.

The Elephant's child asks a "Bi-Coloured - Python - Rock Snake" (49) about the crocodile. This epithet describes the species of the snake. Then the young elephant meets a crocodile and asks him what he has for dinner. At that time the crocodile deceives the Elephant and by his "musky, tusky mouth" he catches him by his little nose (51). There is a rhythmic, onomatopoeic assonance in describing the mouth so as to achieve a funny rhythm. The crocodile ironically replies to the elephant's question "I will begin with the Elephant's child!"(52).

The Elephant's nose hurts him and there is a deliberate humorous misuse of language because he is talking through his nose saying "Led go! You are hurting be"(52). The snake, who is a real friend of the Elephant, advises him to pull his nose as hard as he can. He calls the crocodile "the large - pattern leather ulster" which is an ironic epithet showing the snake's sympathy with the Elephant. As each one of them pulls, the Elephant's nose grows "longer and longer" (52). This fanciful incident stirs the child's imagination and makes him think of the length and benefits of the trunk of the elephant.

The Elephant is about to surrender "This is too butch for be" as he talks through his nose (53). Yet, the snake keeps urging him to resist and pull his nose and he himself helped the Elephant till he gets rid of the crocodile's grasp. In this struggle between the Elephant and the crocodile, the children sympathize with the elephant and hopes that he will win. When the Elephant complains that he has to wait for his nose to shrink because it is badly out of shape, the snake comments "some people do not know what is good for them" (54). He begins to notice the advantages of the trunk and through a kind of rhythmic repetition, he comments on each advantage saying to the Elephant "you couldn't have done that with a mere-smear nose" (55). The assonance between "mere" and "smear" makes the rhythm more wonderful.

The Elephant's child went home across Africa, "frisking and whisking" his trunk (55). The rhythm here shows his happiness and pride of his trunk. An advantage of his trunk appears when he pulls fruits from a tree instead of waiting for it to fall. He also plucks grass from the ground instead of going on his knees to have grass. Humorously he takes his revenge on his relatives for spanking him before. About this end Morpurgo says "no ending of any story was ever or could ever be more gratifying to a child" (Morpurgo). 
There are two illustrations in the story. The first one shows the crocodile while pulling the trunk of the Elephant's child. The second one depicts the elephant while making use of his trunk and pulls banana. The story is followed by a nice poem that praises curiosity as a way of acquiring knowledge and experience. The speaker in the poem personifies the question words as his "serving - men" and also as "hungry men" (62). The personification is very clear when he says that the names of his "six honest serving men" are: "What and Why and When and How and Where and Who" (62). The child thinks of the different question words and their functions through this indirect way. He will not feel shy to ask about anything he does not know.

Leaving the elephant in Africa, Kipling turned to the Kangaroo in Australia. According to "The Sing-Song of Old Man Kangaroo", most of it is written in free verse. As the kangaroo wanted to be different from the other animals, he went to the little God, the Middle God, then the Big God Nqa. The Big God ordered the yellow Dog Dingo to make the kangaroo different from other animals. The Dog begins to chase the kangaroo throughout the whole of Australia.

For the first time in his stories Kipling divides his story into two parts. At this part of the story he addresses his daughter saying: "This, $\mathrm{O}$ Beloved of mine, ends the first part of the tale!" (64). This is because the second part teems with rhythmic repetition and parallel structures that make the story like a poem written in free verse. This is obvious in "He ran through the desert; he ran through the mountains; he ran through the salt - pans; he ran through the reed beds; he ran through the blue gums; he ran through the spinifex" (65). The rhythmic repetition of "he ran through" shows the various places to which he went. Moreover, he ends each paragraph with the sentence "He had to!" (65). This attracts the ear of the child while stirring his curiosity. Kipling seems to enjoy his funny usage of words as he sees the effect of his amusing language on children.

When the kangaroo's legs ached, he began to hop. Again, a parallel structure is used in describing the kangaroo's movement. "He hopped through the Flinders, he hopped through the Cinders, he hopped through the deserts ..." (65). This rhythmic repetition is attractive to the child because it tells the story as if it were a poem. Again parallel description appears in "his legs growing stronger; his legs growing longer" (68). The kangaroo "hopped like a cricket; like a pea in a sauce-pan; or a new rubber ball on a nursery floor"(68). The similes used here besides the 
rhythm and the assonance between "ball" and "floor" give a humorous and interesting imagery.

Parallel structure is used again when the time of changing the kangaroo comes, "Down sat Dingo-Poor Dog Dingo" and "Down sat kangaroo - Old Man Kangaroo" (68). Moreover, rhythmic repetition is used when the kangaroo tells God Nqong how the Dog chased him and made him tired. "He's chased me out of the homes of my childhood; he's chased me out of my regular meal-times; he's altered my shape so I'll never get it back; and he's played Old Scratch with my legs" (69). The Kangaroo means that the Dog has played the devil with his legs. The parallel structure of repeating the verbs in the present perfect tense is used to show the result of what the Dog has made to the Kangaroo. Kipling humorously claims that the hind legs of the Kangaroo are long from that time.

There are two illustrations in the story. The first one shows the Kangaroo when his legs were short and gives him the name of "Boomer" (66).In so doing, he individualizes the kangaroo to create an intimate relationship between him and the child. The second illustration shows the Dog chasing the Kangaroo through the bare hills. The Kangaroo's hind legs have become longer and in his caption Kipling explains that he draws the Kangaroo's pouch as he has to have one. The story is followed by a very long poem of unrhymed verse that depicts the pursuit of the Dog to the Kangaroo throughout different places so that in a parenthesis Kipling says "(Look at the Atlas, please)" (73). This shows that he is so interested in maps and places that he wants children to be aware of them.

After handling the elephant of Africa and the kangaroo of Australia, Kipling turns to the Armadillo of the Amazon. "The Beginning of the Armadilloes" gives a flagrant example of Kipling's wordplay and his deliberate misuse of language. Added to this is his deliberate mixing of nouns and verbs. His main aim in doing so is to attract the child's ear and to amuse him.

In this story Kipling introduces the "Stickly-Prickly" Hedgehog and the "Slow - Solid" tortoise who could deceive the jaguar in order not to eat them. The jaguar's mother advises him that before eating a Hedgehog, he has to drop him into water and he will uncoil. On the other hand, before eating a Tortoise, he must scoop her out of her shell.

One night the jaguar found the Hedgehog and the tortoise and they could not run away. However, he does not know which is the Hedgehog 
and which is the Tortoise. When he tells them that he does not know which is which, they begin to confuse him in order to escape. The stickly - prickly Hedgehog begins deceiving and confusing him. Here, there is a humorous wordplay by which the Hedgehog is telling the jaguar the opposite of his mother's advice. He says to him "Perhaps she said that when you uncoil a Tortoise you must shell him out of the water with a scoop, and when you paw a Hedgehog you must drop him on the shell"(76). This is a deliberate misuse of language with the purpose of mixing things up in the jaguar's mind. The wordplay continues as the Tortoise says "when you scoop water with your paw you uncoil it with a Hedgehog" (77). Moreover, the Hedgehog humorously exploits the Jaguar's ignorance and claims that he is a Tortoise so he addresses the Jaguar "you can scoop me out of my shell if you like"(77). The Hedgehog curls himself up so that the Jaguar's paddy - paw is filled with prickles. He knocked Stickly - Prickly away into the woods as the prickles hurt him badly.

When the Tortoise informs the Jaguar that she is a real Tortoise, he cannot believe her. The wordplay appears here again when the Tortoise discusses with the Jaguar the advice of his mother. She says to him "Well, suppose you say that I said that she said something quite different, I don't see that it makes any difference; because if she said what you said I said she said, it's just the same as if I said what she said she said" (80). This confusion gives a funny and humorous effect. The Jaguar admits to the Tortoise "You've mixed up all the things my mother told me to do --- till I don't know whether I'm on my head or my painted tail" (81). This confusion is achieved by the Tortoise's deliberate misuse of language and the wordplay in which he mixes verbs with nouns. So the jaguar ordered the Tortoise to jump into the turbid Amazon.

Again, there is word game which is suitable for children. This happens when the mother of the Jaguar asks him "What have you been doing that you shouldn't have done?" (82). When he confesses his failure in catching either the Tortoise or the Hedgehog because they are "too clever" (82), she begins to teach him again that a Hedgehog curls himself up and his prickles stick out everywhere. She adds that a Tortoise can't curl himself up. The Jaguar composes a humorous rhyme in which he marks the specific characteristics of the two animals:

Can't curl, but can swim-

Slow - Solid, that's him!

Curls up, but can't swim -

Stickly - Prickly, That's him!" (83). 
For more protection the Stickly - Prickly decides to learn swimming and to encourage the Tortoise to exercise curling up. The Tortoise praises the Hedgehog's swimming with a humorous exaggeration saying that "a little more practice will make you a regular whale" (84). They continue their exercise, each helping the other till they become different from what they had been. When the Jaguar sees them, he cannot know them.

Then both the Tortoise and the Hedgehog curled themselves up and rolled round the Jaguar. He was so confused that "his eyes turned truly cart - wheels in his head" (86). This has a very humorous effect. Here the child becomes very pleased on seeing the success of the tortoise and the hedgehog to save themselves. He may encourage their attempts to deceive the jaguar and admire their skill and persistence. Concerning the children's response to Kipling's stories Daniel Karlin thinks that children "take delight in order and method, in things worked out and resolved, in hierarchy and proper authority. They also delight in rebellion and recalcitrance" (Karlin). There is a humorous wordplay when the Jaguar complains to his mother that he saw two new animals but "the one that you said couldn't swim, swims, and the one that you said couldn't curl up, curls" (86). When the Jaguar tells his mother that the new animal is a little bit of both, she replies that it is called the "Armadillo". From that day on, the animal that lives on the banks of the turbid Amazon is called the Armadillo. Again this is the usual, humorous end of Kipling's stories.

There are two illustrations in this story. The first one depicts a map of the turbid Amazon. The second illustration shows the Jaguar, the Hedgehog, the Tortoise, and the Armadillo "all in a heap" (88). It reflects the confusion that happens in the mind of the jaguar. This is followed by a short poem in which the speaker says that he never sailed the Amazon. Moreover, he has never reached Brazil, and he has never seen a Jaguar or an Armadillo. However, he expresses his wish to go to Rio before becoming old. The poem thus shows the importance of places and travelling for Kipling.

Thus, Just So Stories has a special position among Kipling's work because it shows his unique style in addressing the children's emotions and stirring their imagination. It is the only book he illustrates. Each story has an illustration in the middle of the incidents, and an illustration at the end of the story followed by a poem. The illustrations are accompanied by long and detailed captions that explain everything in the pictures. In so doing, he helps the child to reach a suitable interpretation of the stories. The child has to connect the stories to his familiar world to be able to 
visualize their characters and events. The result of the interactive activity of the child achieves what Iser calls "the virtual dimension of the text" which is a blend of the child's imagination and the stories (Lodge 298). He resorts to his previous knowledge of these animals to be able to imagine their behavior. Moreover, Kipling addresses the children in a very familiar, intimate, and humorous way. The poems are sometimes functional that is to say they are so relevant to the story that they repeat its theme in verse. This happens with the poems of the camel's story that urges children to work and not to be lazy. Furthermore, the poem of the story of the curious young elephant talks about curiosity and the poem of the kangaroo's story handles how his hind legs become longer. However, at other times, the poems are irrelevant and they seem to be just a kind of interesting songs to amuse children.

The other linking theme in the stories is the deliberate misuse of language. Kipling's stories teem with wordplay, misspelling, malapropism and puns. Moreover, there are attractive onomatopoeic adjectives, rhythmic repetitions, parallel structure and rhythmic patterns. Added to this is the exaggeration which has a great humorous effect. The use of parentheses is also notable for adding explanatory but usually humorous details. Randall Jarrel describes Kipling as "a professional magician" whose words hold the ear and draw the eye (Jarrel 138). Moreover, James Harrison ascribes the success of Just So Stories to its dependence on "its simultaneous appeal to both reader and listener" (Harrison 59). Harrison believes that the "story's crowning glory" is due to "the author's unashamed enjoyment of language" which is felt by the adult as a performer and the child as listener (Harrison 60).

Kipling's strong love for folk stories and fables from many lands is revealed through Just so Stories. Yet, what distinguishes him, is his ability to select and blend from the various material he received. This increases the child's enjoyment and stirs his emotions while listening to these wonderful stories. He laughs, anticipates what is coming next, and enjoys the misuse of language. Furthermore, he becomes very happy with the drawings and their joyful characters. Also, he enjoys the lilt of the poems following the stories. However, the child can distinguish the information that can be taken seriously from the humorous details which are part of Kipling's funny style. If the child does not play his vital and active role in interpreting Kipling's stories, he will not be able to enjoy them properly. 


\section{Manal Anwar Fathy Ahmed}

\section{Works Cited}

Abrams, M.H. The Mirror and the Lamp: Romantic Theory and the Critical Tradition. New York: The Norton Library, 1958.

Birkenhead, Lord. Rudyard Kipling. New York: Random House, 1978.

Bodelsen, C.A. Aspects of Kipling's Art. New York: Barnes and Noble, Inc, 1964.

Gilbert, Elliot L. The Good Kipling: Studies in the Short Story. Ohio University Press, 1972.

Guerin, Wilfred L., Labor, Earle, et al. A Handbook of Critical Approaches to Literature. Third Edition. New York and Oxford: Oxford University Press, 1992.

Harrison, James. Rudyard Kipling. Boston: Twayne Publishers, 1982.

Havilland, Virginia. Children's Literature: A Guide to Reference Sources. Washington: Library of Congress, 1966.

Hughes, Felicity A. "Children's Literature: Theory and Practice." ELH, vol.45,no 3. The Johns Hopkins University Press, 1978, pp. 542-561.

Hunt, Peter. Understanding Children's Literature. Second Edition.

London and New York: Routledge, 2005.

Jarrel, Randall. "On Preparing to Read Kipling" Kipling and the Critics. Ed. Gilbert, Elliot. London: Peter Owen, 1965, pp. 133 - 149.

Jones, Malcolm. "It's High Time We Let Rudyard Kipling Out of the Penalty Box". Daily Beast. Matt Wilstein, 05.01.2016, www.the daily beast.com.its-high-time-we-let-rudyard-kipling-out-of-the-penaltybox?ref-scroll. Accessed 25 February2019

"Just So Stories by Rudyard Kipling 1902". Books and Boots: reflections on books and art, https:// astrofella. Wordpress.com/2016/10/11/justso-stories-rudyard-kipling. Accessed3March 2019

Karlin, Daniel. "How the stories got their name: Kipling and the origins of 'Just So Stories'". OUPblog, Oxford U P,23 December 2015, http:// blog.oup.com/ 2015/12/kipling- stories-names/

Kent, S. Kelley. Rudyard Kipling's Literary and Historical Legacy". INQUIRIES,2013,vol.5No.11,www.inquiriesjournal.com/articles/ 817/3/Rudyard-kipling's-literary-and-historical-legacy.Accessed 9 March 2019

Kipling, Rudyard. Just So Stories: for Little Children. Oxford and New York: Oxford University Press, 1995.

Lewis, Lisa. Introduction. Just So Stories by Rudyard Kipling. Oxford and New York: O.U.P., 1995, pp XV - xlii.

Lodge, David and Wood, Nigel. Modern Criticism and Theory: A Reader. Third Edition. Harlow: Pearson Longman, 2008.

MacCann, Donarae \& Richard, Olga. The Child First Books: A Critical Study of Pictures and Texts. New York: The H.W. Wilson Company, 1973. 
Magee, William H. "The Animal Story: a Challenge in Technique". Only Connect : Readings on Children's Literature. $2^{\text {nd }}$ edition. Eds. Egoff, Sheila, and Ashley, L.F. Toronto and New York: Oxford University Press, 1980, pp $221-232$.

Mallan, Kerry. Laugh Lines: Exploring Humor in Children's Literature. Australia: Primary English Teaching Association, 1993.

Mallett, Margaret. Choosing and Using Fiction and Non- Fiction: A Comprehensive Guide for Teachers and Student Teachers. London and New York: Routledge, 2010.

May, Jill P. Children's Literature and Critical Theory. Oxford University Press, 1995.

Medlock, Chelsea. "Kipling's Menagerie: Human-Animal Relations in the Works of Rudyard Kipling". Animal History Museum,2016, animalhistorymuseum.org/ exhibitsandevents/online-gallery/gallery-8animals-and-empire/enter-gallery-8/iii-looking/Rudyard/kipling/

Accessed 6 March 2019

Morpurgo, Michael. "Michael Morpurgo: How Rudyard Kipling's Just So Stories became music to my ears". The Guardian, The Folio Society, www. The guardian.com/books/2013/jan/ou/Rudyard-kipling-just-sostories-ears Accessed 5 March 2019

Newton, K.M. Ed. Twentieth- Century Literary Theory: A Reader. Houndmills: Macmillan Education LTD, 1988.

Oswald, Lori Jo. "Heroes and Victims: The Stereotyping of Animal Characters in Children's Realistic Animal Fiction." In Children's Literature in Education, vol 26 ,No. 2. Human Sciences Press. Inc., 1995.

Page, Norman. A Kipling Companion. London: Macmillan Press, 1984.

"Rudyard kipling's 'Just So Stories'". ON Line Gallery. The British

LibraryBoard,26March2009,www.bl.uk/onlinegallery/onlineex/englih/ kipling/ Accessed 4 March 2019

Selden, Raman, Widdowson, Peter and Brooker, Peter. A Reader's Guide to Contemporary Literary Theory. Fifth Edition. Harlow: Pearson Longman, 2005.

Sipe, Lawrence R. "Children's Response to Literature: Author, Text, Reader, Context." In Theory into Practice,vol.38, No.3. The Ohio State University: College of Education, 1999. 